\title{
13 ANALYSIS OF OUTSOURCING AND THE IMPACT ON BUSINESS RESILIENCE
}

\author{
Pati Milligan \\ Baylor University \\ Waco, TX U.S.A. \\ Donna Hutcheson \\ $X R$ Group, Inc. \\ Dallas, TX U.S.A.
}

\begin{abstract}
Business and corporate resiliency rely on information technology and information systems organizations to outsource the tasks, not the responsibility for adequate service or adequate controls. A key success factor is to outsource procedures and processes that are not "broken" or ineffective. As management examines the viability to outsource all or part of the IT services, a successful plan will always prioritize and assess risks associated with what to outsource, then where (required location of service delivery). then who will provide delivery of the service. Successful IT outsourcing must be carefully managed. Therefore, to help control outsource application project costs, make change control a critical component of the project to be managed with the same cost benefit analysis used to decide on a new process in the beginning. This paper analyzes the risks of outsourcing, trends in outsourcing domestically and offshore, approaches for managing outsourcing, and the legal and regulatory consequences of outsourcing. Each component impacts business and corporation resilience.
\end{abstract}

Keywords IT outsourcing, outsourcing services, off-shore, managing outsourcing, business resilience

\section{INTRODUCTION}

Business and corporate resiliency rely on information technology to outsource tasks, not responsibility for adequate service or controls. A key success factor is to outsource procedures and processes that are not "broken" or ineffective. As management

Please use the following format when citing this chapter:

Milligan, Pati, Hutcheson, Donna, 2006, in International Federation for Information Processing (IFIP), Volume 206, The Transfer and Diffusion of Information Technology for Organizational Resilience, eds. B. Donnellan, Larsen T., Levine L., DeGross J. (Boston: Springer), pp. 199-208. 
examines the viability to outsource all or part of IT services, a plan should be built that will always keep in mind determining what to outsource, where (location of service delivery), then who will provide delivery service.

The issues, concerns, and impact on business resiliency in the era of outsourced services and offshore service delivery are basically the same as before. Evolution of corporate and economic globalization in recent years has mandated a comprehensive analysis of the relationship between resilience in a given geographical location and overall organizational resilience.

\section{RESEARCH CASES}

Six research cases are specifically noted in this report.

1. Company B, a large global petroleum company headquartered in the UK with operations in Europe, the Middle East, Far East, Africa, Australia, and the United States.

2. Company E, a global communications company, headquartered in the Baltics, that develops and supplies advanced systems, products, and services for mobile and fixed-line communications to network operators, with operations in Europe, the Middle East, Africa, Asia Pacific, North America, and Latin America

3. Company F, a consumer products company based in Texas with international operations in Europe, South and Central America, the Caribbean, Canada, the Far East, Australia, and the Middle East.

4. Company H, a large U.S.-based hospital with multiple branch locations.

5. Company O, a U.S.-based private company with multiple business lines,

6. Company U, a premier U.S.-based REIT (real estate investment trust) corporation with large assets and revenue.

\section{REASONS FOR OUTSOURCING}

Headcount reduction: Company $\mathrm{U}$ determined computers and IT were not critical to their operation. Their core competency was buying and leasing real estate or mortgages. So, Company U reduced the internal IT head count to one and outsourced all IT services. IT audits revealed significant problems and control issues. In 2005, Company U was absorbed by another REIT that had a large internal IT service department.

Lack of internal expertise: Company B outsources IT to achieve standardization of IT Technologies wherever possible. Company B has acquired several large petroleum companies whose IT systems used shared services, domestic outsourcing, and 
near-shore outsourcing. Company B's IT strategy has been to retain the existing IT structure for a period of 12 to 18 months, study the service delivery methods that were successful and those that would not fit Company B's overall IT strategy. A team of Company B employees and domestic providers in the acquired corporation's country restructured the IT technology used and the delivery of service. If the acquired company did not have sufficient expertise to convert to the new, common technology, those projects were outsourced. This technique has proven successful from the corporate standpoint, but not from the subsidiary standpoint.

Company F outsources multiple services to multiple providers. Shared services are used for all IT operations (except security) for European and Asian locations. Shared services for ERP applications, networking, and application security for all locations are provided internally at the corporate offices. Internal IT audit services are outsourced domestically or nearshore, depending on availability of qualified audit providers. Company $\mathrm{F}$ examines each task and service needed to support international IT operations, determines where the task or service should be provided, then who should provide the service or complete the task. The resiliency of Company $\mathrm{F}$ has been proven strong over the past 5 years. Stock price and dividends have financial analysts advising to buy or hold.

Emerging technologies: Emerging technologies were always implemented into the corporation through a combination of contingency staffing and domestic providers. Depending on the complexity of the emerging technology and the level of associated training, outsourcing has roughly equal success and failure histories.

Network outsourcing: Company E outsources all IT services-some effectively, others fraught with problems. Company E outsources all telecommunications to other network operators, both global and domestic to office locations. They also provide hosting services to global network providers. The theory is that Company E's core competencies are the advanced solution design and operation of switches and routers. Company $\mathrm{E}$ is a leader in this hosting service.

ERP applications: Company E uses IBM as the sole provider for ERP application implementation globally. Because IBM has outsourced a major portion of Company E's application tailoring and implementation, the hybrid form of provider services has added a complexity resulting in many problems for the North America division of Company E. First-level application support is provided globally by HP, thus adding another layer of complexity and opportunity for miscommunication.

Company E's North America division conducted an IT application audit. Segregation of duties issues were numerous. Finding and correcting the profile security problems was outsourced to a third-party provider (one specializing in IT audits). A problem was identified and corrected in the developer instance of the ERP software. The other respective service providers were notified of the requirement to migrate. Migration failed. The resulting research took three days to locate and correct the cause of the migration failure; it should have taken less than an hour. The design and flow of code from development to test to production was the cause. This situation is common at Company E. Red tape, communication across time zones, finger pointing, and lack of total picture by any one provider severely impacts the resilience of IT. However, corporate executives state that it has no impact on the resilience of the business. Many outside consultants and auditors view Company E's outsourced operations as a massive hemorrhage. 
$D B M S$ : Company B stores the master data for all enterprise systems at headquarters IT. Local data and replicas of enterprise data are stored at domestic provider locations. All DBMS support is provided by domestic providers.

Company $\mathrm{E}$ relies on HP to manage storage and location for all data and DBMS support.

Company F stores enterprise data at headquarters. All local data is provided by the shared services groups. All DBMS support is provided by headquarters IT staff.

All three companies view the outsourced DBMS as a success story.

Web presence: All small to medium U.S. companies outsourced design and hosting of websites to domestic providers. Content was provided and/or approved by corporate headquarters. Corporate IT groups did not participate. A total of 75 percent of medium to large global companies provided design and hosting of the website in-house; the other 25 percent outsourced to domestic providers. This is a successful service with minimal costs.

Business transformation or change in business strategies: As management reviews short and long term business and IT strategies, new requirements emerge. Most often noted is the requirement to provide $24 / 7$ monitoring of IT infrastructure, and 24/7 call centers to cover global time zones. Monitoring IT $24 / 7$ by offshore or domestic providers is reported to be most satisfactory with minimum problems. Call centers tend to have a dichotomy: high success is reported by providers and inadequate success is reported by internal users and external clients. How does this different perspective affect the resilience of the business?

Disaster recovery/business continuity planning: Standardization across borders is essential to maintaining business resilience in the face of natural disaster or political unrest. Disaster recovery can be instant and seamless if business processes can be done at any location. The major impact of natural disasters can be avoided by moving services before the disaster hits. A recent example is the short downtime of companies in New Orleans with comprehensive disaster recovery plans for hot recovery sites in various parts of the world. Likewise, companies that had outsourcing agreements with providers in other areas had minimal downtime. Businesses with neither plan have a resilience factor of 0 , affecting company survival.

Internal political issues: Upper management is disappointed with previous IT solutions, so the $\mathrm{CIO}$ upgrades or replaces a legacy system with new systems or new technology. Often the decision is made to outsource selection, tailoring, and implementation before determining why the legacy system did not meet executive needs and whether a new system or technology will succeed where the legacy system failed. Was it the system and technology or was it the design and procedures?

\section{PROS, CONS, AND RISKS}

Multisourcing allows companies to select "best of breed" providers in a competitive market. Best of breed involves using the best provider for a particular IT service category or subcategory. A disadvantage is the compound management of multiple service relationships. 
Single source outsourcing results in communication with a single management contact for accountability. It also limits the "blame game." A caveat for single source is that too often the buyer requests a service from the provider that is not in the provider's core competence area.

Total IT services outsourcing (one or more providers) plans for the arrangement to last from 8 to 10 years. Total IT outsourcing was one of the major reasons for collapse of Company $U$ above. Conversely, if a company has no cutting edge technology or special IT requirements, total outsourcing can work.

Selective sourcing allows companies to choose subtasks rather than an entire business process as in total sourcing. A key consideration when deciding is what the buyer does best versus what can be done better by outsourcing. Companies B, E, F, and $\mathrm{H}$ achieved high success in outsourcing desktop maintenance and support for hardware and software. All buyers' management teams state that this strategy has improved response time, cost, and business staff productivity. Internal help desk support for ERP applications outsourced offshore achieved less than satisfactory results for Company B and Company E. First-level business management at Company B and Company E report that staff productivity has negatively impacted their productivity.

Frequently in business, past "war stories" negatively affect our decisions regarding outsourcing opportunities. For example, a failure in outsourcing the internal help desk colors our judgment about outsourcing desktop maintenance. Each company experience improves the ability to positively contribute to the resiliency of the business through outsourcing appropriate tasks. Not every company benefits from outsourcing. Outsourcing decisions are interlinked with individual business cases and often it is better to retain the process in-house. The $\mathrm{CIO}$ of Company $\mathrm{O}$, states he is against outsourcing for IT. He believes benefits initially gained from outsourcing IT services are lost within 2 years and that it takes twice as long to recover from the negative impact to the business.

To ensure resilience of the service relations, the management team should (1) complete due diligence to discover the capabilities of each party in the final set of providers, (2) establish baseline documents of current performance, and (3) research benchmark studies to measure expected performance against industry norms.

If buyers need global service delivery, then it is essential that the chosen provider have global infrastructure and business continuity to support the buyer's requirements.

Successful outsource agreements result when companies have well-defined outsource strategies with specific contracting and negotiation plans. These plans should include both market and business impact analysis.

If internal user dissatisfaction with outsourced services is severe enough, internal departments will find ways to circumvent some portion of the outsourced service. Example: Company E has several departments that believe the procedures associated with server, application, and data security operations prohibit them from doing their jobs efficiently. Departments purchase servers, charge them as expense line-items, install appropriate applications, store the department data, and run department business totally outside the outsource process. What happens to business resiliency when a problem occurs with the server, application, or data? 
Table 1. Pros and Risks to Business Resiliency

\begin{tabular}{|c|c|}
\hline Pro & Risks to Business Resiliency \\
\hline \multicolumn{2}{|l|}{ Logical Security } \\
\hline $\begin{array}{l}\text { - Provider cost and maintenance fee } \\
\text { distributed among clients } \\
\text { - Rapid updates with live monitoring } \\
\text { - Dedicated staff with up to date knowledge }\end{array}$ & $\begin{array}{l}\text { - Loss or unauthorized access of data } \\
\text { - Data integrity } \\
\text { - Failure to fully design, develop and } \\
\text { implement enterprise security architecture } \\
\text { - Rely primarily on the firewall } \\
\text { - Failure to understand the relationship } \\
\text { security has with the organization }\end{array}$ \\
\hline \multicolumn{2}{|l|}{ Specialized Service } \\
\hline - No in-house training & $\begin{array}{l}\text { - Inability to support service during ongoing } \\
\text { operation }\end{array}$ \\
\hline \multicolumn{2}{|l|}{ Desktop and Server Maintenance } \\
\hline $\begin{array}{l}\text { - Remote control } \\
\text { - Consistent version control } \\
\text { - } 45 \% \text { reduction in IT costs per employee }\end{array}$ & $\begin{array}{l}\text { - Inaccurate/corrupted data and process } \\
\text { integrity } \\
\text { - Inadequate built-in controls } \\
\text { - Few written procedures } \\
\text { - Inadequate unauthorized access protection } \\
\text { - Unapproved change implementation } \\
\text { - Failure to maintain the application } \\
\text { - Intellectual property theft } \\
\text { - Customer information lost, manipulated or } \\
\text { - stolen }\end{array}$ \\
\hline \multicolumn{2}{|l|}{ Disaster Recovery } \\
\hline $\begin{array}{l}\text { - Frequently outsourced IT service } \\
\text { - Well established outsource service } \\
\text { - Service costs: low maintenance and does } \\
\text { not require dedicated full-time staff } \\
\text { - Reduces risk of destroying company } \\
\text { business }\end{array}$ & $\begin{array}{l}\text { - Hot/cold recovery } \\
\text { - Data access and integrity } \\
\text { - Business/customer service disruption } \\
\text { - Financial/external report misstatement } \\
\text { - Lack of staff to support recovery } \\
\text { - Access to recent back-up }\end{array}$ \\
\hline \multicolumn{2}{|l|}{ Voice and Data Telecommunications } \\
\hline - Well established outsource service & $\begin{array}{l}\text { - Illegal/malicious hacking } \\
\text { - Denial of service attacks } \\
\text { - Data corruption } \\
\text { - Bottlenecks } \\
\text { - Slow response times }\end{array}$ \\
\hline \multicolumn{2}{|l|}{ Infrastructure Operations } \\
\hline $\begin{array}{l}\text { No need for land or building to house } \\
\text { equipment/personnel }\end{array}$ & $\begin{array}{l}\text { - Inadequate buyer risk assessment } \\
\text { - Inadequate provider controls and } \\
\text { ineffective monitoring } \\
\text { - Lack of strategic planning to meet buyer's } \\
\text { needs } \\
\text { - Failure to maintain the system }\end{array}$ \\
\hline
\end{tabular}




\begin{tabular}{|c|c|}
\hline Pro & Risks to Business Resiliency \\
\hline \multicolumn{2}{|l|}{ Application Development and Maintenance } \\
\hline $\begin{array}{l}\text { - Does not pay provider during downtime } \\
\text { - No need to interview, hire, train team } \\
\text { members } \\
\text { - No direct management of team members }\end{array}$ & $\begin{array}{l}\text { - Inefficiencies in the business process } \\
\text { supported by the application } \\
\text { Inadequate contingency strategies for } \\
\text { delayed projects } \\
\text { - Average outsourced projects are } \\
\text { completed successfully and effectively } \\
63 \% \text { of the time }\end{array}$ \\
\hline \multicolumn{2}{|l|}{ Help Desk: Internal/Customer } \\
\hline $\begin{array}{l}\text { Less knowledgeable technicians can } \\
\text { resolve } 80 \% \text { of all help desk calls }\end{array}$ & $\begin{array}{l}\text { - Information may not be shared among } \\
\text { buyer departments and providers } \\
\text { - Conflicting behavior or solutions from the } \\
\text { provider team } \\
\text { - Difficulty in identifying performance } \\
\text { trends or problems } \\
\text { - Inability to respond quickly to changing } \\
\text { market conditions } \\
\text { - Loss of revenue from customer } \\
\text { dissatisfaction } \\
\text { - Customer requirements may be } \\
\text { misunderstood } \\
\text { - Provider staff may not be trained to meet } \\
\text { customer needs effectively } \\
\text { - Inaccurate reporting } \\
\text { - Provider employees may breach } \\
\text { organization standards related to security } \\
\text { and confidentiality } \\
\text { - Incomplete/inaccurate recording and } \\
\text { communication of problem- common or } \\
\text { critical } \\
\text { - Cultural differences may interfere with } \\
\text { escalation of problems to appropriate } \\
\text { buyer staff } \\
\text { - Key decision-makers may not be aligned } \\
\text { with day-to-day operations }\end{array}$ \\
\hline
\end{tabular}

\section{COSTS OF OUTSOURCING}

Outsourced customer service operations can cost almost a third more than those retained in-house. Of organizations that outsource customer management operations purely to cut costs, 80 percent will fail to do so, while 60 percent of those who outsource parts of the customer facing process will have to deal with customer defections and hidden costs that outweigh any potential savings offered by outsourcing.

Providers may not be financially viable resulting in premature termination of the service the number of buyers prematurely terminating an outsourcing relationship has doubled to 51 percent while the number of buyers satisfied with their off-shoring 
providers has plummeted from 79 to 62 percent. Outsourcing of any strategic or ineffective process is doomed to failure.

Total costs, including functional interdependencies of outsourced functions are critical to understanding the additional costs of indirectly related functions. The following costs are among those often overlooked in the cost analysis:

- Feasibility study costs.

- Travel expenses to oversee projects or audit.

- More frequent, extensive audits.

- Different auditing practices among countries.

- Theft and piracy.

- Shipping losses.

- Additional administration and paperwork.

- Training and turnover - retraining in the buyer's business goals and processes.

- Cultural and communication difficulties.

- Hidden costs - companies absorbed cost assumed to be the responsibility of the provider resulting in the net effect of no savings from the outsourcing. To maximize the positive impact on company resilience, selection criteria must also prioritize experience; cultural fit, similar work ethics and vision will assure a more effective outsourcing relationship.

- Legal services.

- Offshore practice of state-owned equipment financing.

- Initial cost reductions may be lost as economies supplying cheaper skills are inflated by the influx of business.

- Longer process path from initiation to completion.

- Stronger controls increase costs.

- Salaries of other IT and business support personnel directly related to the service.

- Offshore facilitation and cultural-related costs for offshore outsourcing (under the table payments to receive priority state-controlled services).

- Country-specific risks - stability of political or economic environment, utility and transportation infrastructure

\section{OUTSOURCED SERVICES REALITY}

Outsourcing agreements impact more than the touch point between buyer and provider. Network connections, including those to other buyer IT resources, other provider IT resources, and the Internet, must be secured at all connecting points, regardless of location, to ensure that access is controlled. If buyer management does not monitor network points, buyer resources are vulnerable to attack and penetration. Reporting should include a chart showing the IT services, all locations where they are delivered (buyer side and provider side), and the type and level of controls and security in place.

Performance metrics design, frequency, and breadth can determine outsourcing success or failure. To be effective, performance metrics should be specific, measurable, time or value based, and relevant to the provider and service being outsourced. A com- 


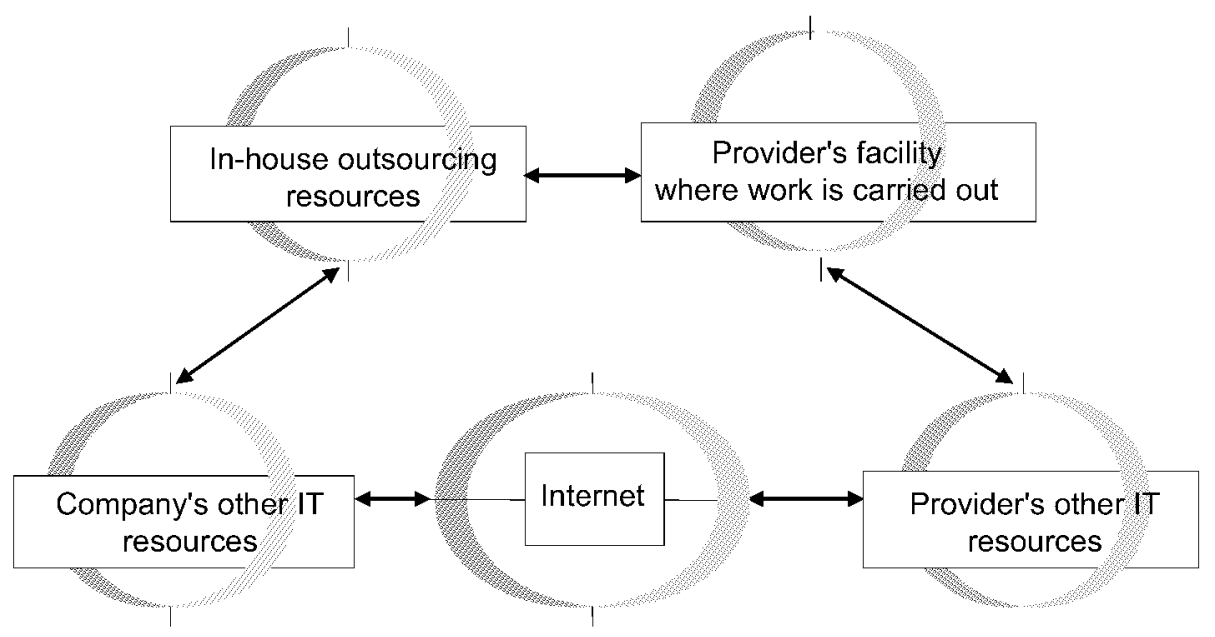

Figure 1. Outsourcing Connection Points

mon example in help desk services: A performance metric may be that 75 percent of all problems are resolved in the first contact. Providers may close problems as resolved when in fact the client is not satisfied. Specific examples of poor metrics: Company $U$ included in the service agreement that provider would supply support as requested by the IT administrator. How is the quality of the provider performance measured? Company $\mathrm{E}$ included performance measures in the service agreement for workstation acquisition, installation, and maintenance. The following data is collected and reported on a rolling 13 month basis: the number of planned workstations by division, department, and location; the number of actual workstations by division, department, and location. Another example: 95 percent of all workstation equipment repairs will be completed and returned to the employee within 1 business day. Routine reviews of the contract helps ensure support of business resiliency. Between 30 and 50 percent of IT outsource contracts need to be substantially renegotiated.

\section{CONCLUSION}

Outsource providers will no longer be able to compete on price alone. Providers must proactively add value. Reduced cost does not always result in retained or created value. Offshore cost benefits will gravitate toward the level of home territory options.

Buyers will focus more on what service is outsourced, where the service is delivered, and who provides that service. To help ensure business resiliency, buyers will contract with providers they know will respect controls, performance, and growth with the buyers. Change and relationships will continue to be primary factors in the future of IT outsourcing. For the complete paper, please contact the authors. 


\section{About the Authors}

Pati Milligan is an associate professor of Information Systems at Baylor University. She received her Ph.D. from University of North Texas and master's degrees from Texas A\&M University and Texas A\&M Commerce. Her research interests include electronic commerce and IT auditing. Pati teaches client/server applications and VB programming courses at the graduate and undergraduate level in the business school. Prior to joining the faculty at Baylor in 1983, Pati spent 3 years in the insurance industry. Pati can be reached at pati_milligan@baylor.edu.

Donna Hutcheson is Principal and CEO of XR Group, Inc., responsible for executive IT consulting and IT auditing at global and domestic USA corporations. Her goal is to ensure that clients' technology foundations are cost effective, meet the client corporations' business goals, and provide for transacting business in a global economy, one which is increasingly influenced by the Internet. Donna began her career by teaching computer science at the graduate and undergraduate level. She moved to industry with the Atlantic Richfield Company (ARCO) where she spent more than 20 years serving in a wide variety of management roles, including training, client services, operations, operations support, planning, groupware and artificial intelligence, international office technology implementations, and international IT auditing. She currently serves on the executive board of the North Texas Chapter of the Information Systems Audit and Control Association, and on the Industry Advisory Board of the Audit Programs at University of North Texas, University of Texas at Dallas, Texas A\&M Commerce, and Tarrant County College. She can be reached by e-mail at dhutch $(a$ xrgroup.com. 